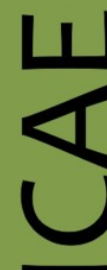

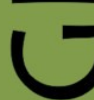

ex Instituto Archaeologico Universitatis de Rolando Eötvös nominatae

O

$\overrightarrow{0}$

山

$\leftarrow$

I

$\cup$

ه

$\leftarrow$

u

Ш

Z

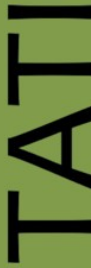

œ

ш

n

n

$\varnothing$
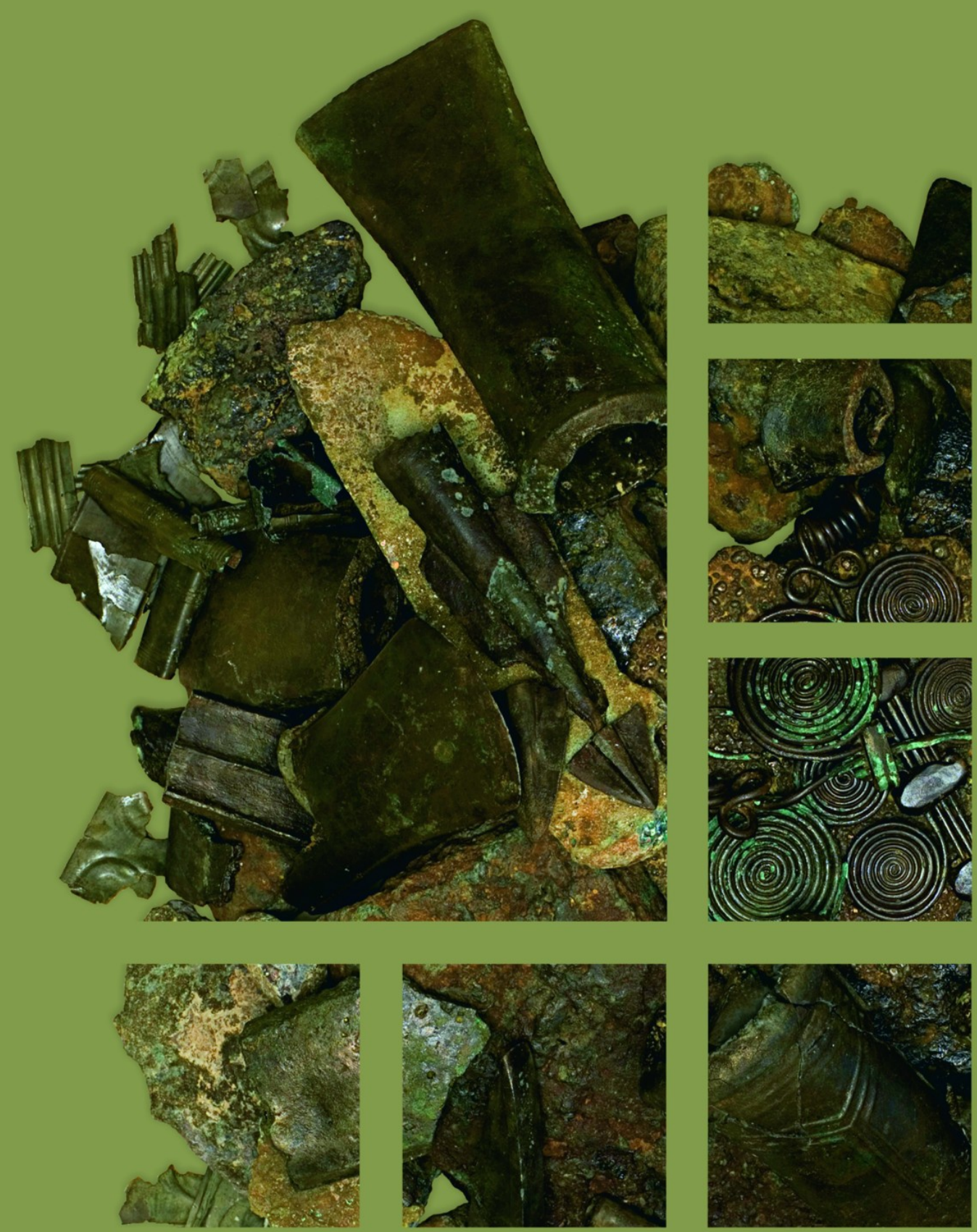


\section{Dissertationes Archaeologicae ex Instituto Archaeologico}

Universitatis de Rolando Eötvös nominatae Ser. 3. No. 2.

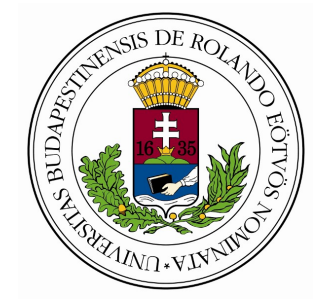

Budapest 2014 
Dissertationes Archaeologicae ex Instituto Archaeologico Universitatis de Rolando Eötvös nominatae

Ser. 3. No. 2.

Editor-in-chief:

DÁvid BARTus

Editorial board:

LÁsZló BARTOSIEWICZ

LÁSZLÓ BORHY

IsTVÁN FELD

GÁBOR KALLA

PÁL RACZKY

MiKLÓs SzABÓ

TIVADAR VIDA

Technical editors:

DÁvid BARTus

GÁBOR VÁCZI

ANDRÁs BÖDŐCS

DÁNIEL SZABÓ

Proofreading:

SZILVIA SzÖLLősI

Available online at http://dissarch.elte.hu Contact: dissarch@btk.elte.hu

$$
\begin{aligned}
& \text { PUBLIC } \\
& \text { KNOWLEDGE } \\
& \text { PROJECT }
\end{aligned}
$$

(c) Eötvös Loránd University, Institute of Archaeological Sciences

Budapest 2014 


\section{Contents}

\section{SElected PAPERS OF THE XI. Hungarian CONFERENCE on Classical Studies}

Ferenc BARNA

Venus mit Waffen. Die Darstellungen und die Rolle der Göttin in der Münzpropaganda

der Zeit der Soldatenkaiser (235-284 n. Chr.)

Dénes GABLER

A belsó vámok szerepe a rajnai és a dunai provinciák importált kerámiaspektrumában

Lajos MATHÉDESZ

Római bélyeges téglák a komáromi Duna Menti Múzeum gyújteményében

Katalin OtTOMÁNYI

Újabb római vicusok Aquincum territoriumán

Eszter SÜVEGH

Hellenistic grotesque terracotta figurines. Problems of iconographical interpretation

András SzABó

Some notes on the rings with sacred inscriptions from Pannonia

István VIDA

The coinage of Flavia Maxima Helena

\section{Articles}

Gábor TARBAY

Late Bronze Age depot from the foothills of the Pilis Mountains

Csilla SÁRó

Roman brooches from Paks-Gyapa - Rosti-puszta

András BöDőcs - Gábor KovÁcs - Krisztián ANDERKó

The impact of the roman agriculture on the territory of Savaria

Lajos JuHÁsz

Two new Roman bronzes with Suebian nodus from Brigetio

\section{FIELD REPORTS}

Zsolt MESTER - Norbert FARAGó - Attila KirÁLy

The first in situ Old Stone Age assemblage from the Rába Valley, Northwestern Hungary

Pál RACZky - Alexandra ANDERs - Norbert FARAgó - Gábor MÁRKus

Short report on the 2014 excavations at Polgár-Csőszhalom 
Preliminary Report on the first season of fieldwork in Berettyóúffalu-Szilhalom

Márton SzILÁgyi - András FüZESI - Attila VIRÁG - Mihály GASPARIK

A Palaeolithic mammoth bone deposit and a Late Copper Age Baden settlement and enclosure

Preliminary report on the rescue excavation at Szurdokpüspöki - Hosszú-dúlö II-III. (M21 site No. 6-7)

Kristóf FüLÖP - Gábor VÁcZI

Preliminary report on the excavation of a new Late Bronze Age cemetery

from fobbágyi (North Hungary)

Lőrinc TimÁr - Zoltán CzAJLik - András BöDőcs - Sándor PuszTA

Geophysical prospection on the Pâture du Couvent (Bibracte, France). The campaign of 2014

Dávid BARtus - László Borhy - Gabriella Delbó - Emese SzÁmadó

Short report on the excavations in the civil town of Brigetio (Szőny-Vásártér) in 2014

Dávid BARTus - László BorHy - Emese SzÁMADó

A new Roman bath in the canabae of Brigetio

Short report on the excavations at the site Szőny-Dunapart in 2014

Dávid BARTus - László Borhy - Zoltán CzAjlik - Balázs Holl -

Sándor PuszTA - László RuPNiK

Topographical research in the canabae of Brigetio in 2014

Zoltán CZAJLIK - Sándor BERECKI - László RUPNIK

Aerial Geoarchaeological Survey in the Valleys of the Mureș and Arieș Rivers (2009-2013)

Maxim MoRDovin

Short report on the excavations in 2014 of the Department of Hungarian Medieval

and Early Modern Archaeology (Eötvös Loránd University, Budapest)

Excavations at Castles Čabrad' and Drégely, and at the Pauline Friary at Sáska

\section{Thesis Abstracts}

Piroska Csengeri

Late groups of the Alföld Linear Pottery culture in north-eastern Hungary

New results of the research in Borsod-Abaúj-Zemplén County

Ádám Bíró

Weapons in the 10-11th century Carpathian Basin

Studies in weapon technology and methodology - rigid bow applications and southern import

swords in the archaeological material

Márta DARÓcZI-SzABó

Animal remains from the mid 12th-13th century (Árpád Period) village of Kána, Hungary

Károly BELÉNYESY

A 15th-16th century cannon foundry workshop in Buda

Craftsmen and technology of cannon moulding and the transformation of military technology

from the Renaissance to the Post Medieval Period 
István RINGER

Manorial and urban manufactories in the 17th century in Sárospatak

\section{BIBLIOGRAPHY}

László BORHY

565

Bibliography of the excavations in Brigetio (1992-2014) 


\title{
Bibliography of the excavations in Brigetio (1992-2014)
}

\author{
LÁSZLÓ BORHY \\ Institute of Archaeological Sciences \\ Eötvös Loránd University \\ lborhy@hotmail.com
}

\begin{abstract}
The following list is the complete bibliography of the excavations and research in Brigetio from the beginning of the fieldwork at the site "Szőny-Vásártér" in 1992, until the end of 2014.
\end{abstract}

\section{4}

BARTUS, D.: A new Roman terracotta mould for lead Mercurius figurines from Brigetio. In: Novotná, M. et al. (eds.): Arts and crafts over the passage of time. Proceedings of the International Conference, Pezinok, 18-21 October 2012. Anodos. Studies of the Ancient World 11 (2011). Trnava 2014, 29-36.

BARTus, D.: Terrakotta öntőforma ólom Mercurius szobrok készítéséhez Brigetióból. In: BALÁzs, P. (ed.): Firkák III. Fiatal Római Koros Régészek III. Konferenciakötete. Szombathely 2014, 161-180.

Bartus, D. - Borhy, L. - Czajlik, Z. - Holl, B. - Puszta, S. - Rupnik, L.: Topographical research at the canabae of Brigetio (2013-2014). Dissertationes Archaeologicae Ser. 3. No. 2 (2014) 451-457.

Bartus, D. - Borhy, L. - SzÁmadó, E.: Short report on the excavations in the civil town of Brigetio (Szőny-Vásártér) in 2014. Dissertationes Archaeologicae Ser. 3. No. 2 (2014) 431-436.

Bartus, D. - Borhy, L. - Delbó, G. - SzÁmadó, E.: A new Roman bath in the canabae of Brigetio. Short report on the excavations at the site Szonny-Dunapart in 2014. Dissertationes Archaeologicae Ser. 3. No. 2 (2014) 437-449.

Bartus, D. - Borhy, L. - Delbó, G. - Dévai, K. - Kis, Z. - Nagy, A. - Sey, N. - SzÁmadó, E. - Szórádi, Zs. - VIDA, I.: Jelentés a Komárom-Szőny, Vásártéren 2011-ben folytatott régészeti feltárások eredményeiről - Bericht über die Ergebnisse der im Jahre 2011 in Brigetio (FO: Komárom/Szőny, Vásártér) geführten archäologischen Ausgrabungen. Kuny Domokos Múzeum Közleményei 19 (2013) [2014] 9-94.

Bartus, D. - Borhy, L. - Delbó, G. - Dévai, K. - Kis, Z. - Nagy, A. - Sey, N. - Számadó, E. - Vida, I.: Jelentés a Komárom-Szőny, Vásártéren 2012-ben folytatott régészeti feltárások eredményeiről - Bericht über die Ergebnisse der im Jahre 2012 in Brigetio (FO: Komárom/Szőny, Vásártér) geführten archäologischen Ausgrabungen. Kuny Domokos Múzeum Közleményei 20 (2014) 33-90.

Bartus, D. - Borhy, L. - SzÁmadó, E.: Régészeti feltárások Komárom-Esztergom megyében 2012-ben. Komárom-Szőny, Vásártér. Kuny Domokos Múzeum Közleményei 19 (2013) [2014] 173-174.

Borhy, L.: Genio Romano. Mérföldkövekből emelt emlékmű Komárom határában. In: Kovács, P. Fenér, B. (eds.): Felirattani újdonságok 2014-ben. Studia Epigraphica Pannonica 6. Budapest 2014, 120-130. 
Borhy, L.: Bélyeges téglák. In: Bartus, D. - Borhy, L. - Delbó, G. - Dévai, K. - Kis, Z. - Nagy, A. SEy, N. - SzÁmAdó, E. - SzóRÁdi, Zs. - VIDA, I.: Jelentés a Komárom-Szőny, Vásártéren 2011ben folytatott régészeti feltárások eredményeiről - Bericht über die Ergebnisse der im Jahre 2011 in Brigetio (FO: Komárom/Szőny, Vásártér) geführten archäologischen Ausgrabungen. Kuny Domokos Múzeum Közleményei 19 (2013) [2014] 12-15.

Borhy, L.: Bélyeges téglák. In: Bartus, D. - Borhy, L. - Delbó, G. - Dévai, K. - Kis, Z. - Nagy, A. Sey, N. - SzÁmadó, E. - VIDA, I.: Jelentés a Komárom-Szőny, Vásártéren 2012-ben folytatott régészeti feltárások eredményeiről - Bericht über die Ergebnisse der im Jahre 2012 in Brigetio (FO: Komárom/Szőny, Vásártér) geführten archäologischen Ausgrabungen. Kuny Domokos Múzeum Közleményei 20 (2014) 37-39.

Borhy, L.: Bibliography of the excavations in Brigetio (1992-2014). Dissertationes Archaeologicae Ser. 3. No. 2 (2014) 565-580.

Borhy, L. - Bartus, D. - SzÁmadó, E.: A régészeti feltárás eredményei. In: Bartus, D. - Borhy, L. Delbó, G. - Dévai, K. - Kis, Z. - Nagy, A. - Sey, N. - Számadó, E. - Szórádi, Zs. - Vida, I.: Jelentés a Komárom-Szőny, Vásártéren 2011-ben folytatott régészeti feltárások eredményeiről - Bericht über die Ergebnisse der im Jahre 2011 in Brigetio (FO: Komárom/Szőny, Vásártér) geführten archäologischen Ausgrabungen. Kuny Domokos Múzeum Közleményei 19 (2013) [2014] 9-12.

Borhy, L. - Bartus, D. - SzÁmadó, E.: A régészeti feltárás eredményei. In: Bartus, D. - Borhy, L. Delbó, G. - Dévai, K. - Kis, Z. - Nagy, A. - Sey, N. - Számadó, E. - Vida, I.: Jelentés a Komárom-Szőny, Vásártéren 2012-ben folytatott régészeti feltárások eredményeiről - Bericht über die Ergebnisse der im Jahre 2012 in Brigetio (FO: Komárom/Szőny, Vásártér) geführten archäologischen Ausgrabungen. Kuny Domokos Múzeum Közleményei 20 (2014) 33-36.

Borhy, L. - SzÁmadó, E. - BARTus, D.: Részlet a 2013. év ásatási beszámolójából. In: Dobosi L.: Városi lakóházépitészet Brigetióban. Acta Archaeologica Brigetionensia Ser. I. Vol. 6. A komáromi Klapka György Múzeum katalógusai XX. Komárom 2014, 46-49.

Delbó, G.: Helyi kerámiák. In: Bartus, D. - Borhy, L. - Delbó, G. - Dévai, K. - Kis, Z. - Nagy, A. SEy, N. - SzÁmAdó, E. - SzóRÁdi, Zs. - VIDA, I.: Jelentés a Komárom-Szőny, Vásártéren 2011ben folytatott régészeti feltárások eredményeiről - Bericht über die Ergebnisse der im Jahre 2011 in Brigetio (FO: Komárom/Szőny, Vásártér) geführten archäologischen Ausgrabungen. Kuny Domokos Múzeum Közleményei 19 (2013) [2014] 27-30.

Delbó, G.: Helyi kerámia. In: Bartus, D. - Borhy, L. - Delbó, G. - Dévai, K. - Kis, Z. - Nagy, A. Sey, N. - SzÁmadó, E. - VIDA, I.: Jelentés a Komárom-Szőny, Vásártéren 2012-ben folytatott régészeti feltárások eredményeiről - Bericht über die Ergebnisse der im Jahre 2012 in Brigetio (FO: Komárom/Szőny, Vásártér) geführten archäologischen Ausgrabungen. Kuny Domokos Múzeum Közleményei 20 (2014) 40-44.

Dévai, K.: Üvegleletek. In: Bartus, D. - Borhy, L. - Delbó, G. - Dévai, K. - Kis, Z. - Nagy, A. Sey, N. - SzÁmadó, E. - SzóRÁdi, Zs. - VIDA, I.: Jelentés a Komárom-Szőny, Vásártéren 2011ben folytatott régészeti feltárások eredményeiről - Bericht über die Ergebnisse der im Jahre 2011 in Brigetio (FO: Komárom/Szőny, Vásártér) geführten archäologischen Ausgrabungen. Kuny Domokos Múzeum Közleményei 19 (2013) [2014] 16-27.

Dévai, K.: Üvegleletek. In: Bartus, D. - Borhy, L. - Delbó, G. - Dévai, K. - Kis, Z. - Nagy, A. SEY, N. - SzÁmAdó, E. - VIDA, I.: Jelentés a Komárom-Szőny, Vásártéren 2012-ben folytatott régészeti feltárások eredményeiről - Bericht über die Ergebnisse der im Jahre 2012 in Brigetio (FO: Komárom/Szőny, Vásártér) geführten archäologischen Ausgrabungen. Kuny Domokos Múzeum Közleményei 20 (2014) 44-54. 
Doвоsi, L.: Városi lakóházépitészet Brigetióban. A Komárom/Szőny-Vásártér lelőhelyen 1992-2013 között folytatott ásatások épitészeti vonatkozású eredményei. Acta Archaeologica Brigetionensia Ser. I. Vol. 6. Komárom 2014.

Kis, Z.: Importkerámia és mécsesek. In: Bartus, D. - Borhy, L. - Delbó, G. - Dévai, K. - Kis, Z. Nagy, A. - Sey, N. - SzÁmadó, E. - SzóRÁdi, Zs. - VidA, I.: Jelentés a Komárom-Szőny, Vásártéren 2011-ben folytatott régészeti feltárások eredményeiről - Bericht über die Ergebnisse der im Jahre 2011 in Brigetio (FO: Komárom/Szőny, Vásártér) geführten archäologischen Ausgrabungen. Kuny Domokos Múzeum Közleményei 19 (2013) [2014] 30-32.

Kis, Z.: Import kerámiák és mécsesek. In: Bartus, D. - Borhy, L. - Delbó, G. - Dévai, K. - Kis, Z. Nagy, A. - Sey, N. - SzÁmadó, E. - VidA, I.: Jelentés a Komárom-Szőny, Vásártéren 2012-ben folytatott régészeti feltárások eredményeiről - Bericht über die Ergebnisse der im Jahre 2012 in Brigetio (FO: Komárom/Szőny, Vásártér) geführten archäologischen Ausgrabungen. Kuny Domokos Múzeum Közleményei 20 (2014) 54-59.

Nagy, A.: Amphorák. In: Bartus, D. - Borhy, L. - Delbó, G. - Dévai, K. - Kis, Z. - Nagy, A. - Sey, N. - SzÁmadó, E. - SzóRÁdi, Zs. - VIDA, I.: Jelentés a Komárom-Szőny, Vásártéren 2011-ben folytatott régészeti feltárások eredményeiről - Bericht über die Ergebnisse der im Jahre 2011 in Brigetio (FO: Komárom/Szőny, Vásártér) geführten archäologischen Ausgrabungen. Kuny Domokos Múzeum Közleményei 19 (2013) [2014] 32-35.

Nagy, A.: Amphorák. In: Bartus, D. - Borhy, L. - Delbó, G. - Dévai, K. - Kis, Z. - Nagy, A. - Sey, N. - SzÁmadó, E. - VIDA, I.: Jelentés a Komárom-Szőny, Vásártéren 2012-ben folytatott régészeti feltárások eredményeiről - Bericht über die Ergebnisse der im Jahre 2012 in Brigetio (FO: Komárom/Szőny, Vásártér) geführten archäologischen Ausgrabungen. Kuny Domokos Múzeum Közleményei 20 (2014) 59-60.

Sey, N.: Bronztárgyak. In: Bartus, D. - Borhy, L. - Delbó, G. - Dévai, K. - Kis, Z. - Nagy, A. - Sey, N. - SzÁmAdó, E. - SzóRÁdi, Zs. - VIDA, I.: Jelentés a Komárom-Szőny, Vásártéren 2011-ben folytatott régészeti feltárások eredményeiről - Bericht über die Ergebnisse der im Jahre 2011 in Brigetio (FO: Komárom/Szőny, Vásártér) geführten archäologischen Ausgrabungen. Kuny Domokos Múzeum Közleményei 19 (2013) [2014] 57-59.

Sey, N.: Bronztárgyak. In: Bartus, D. - Borhy, L. - Delbó, G. - Dévai, K. - Kis, Z. - Nagy, A. - Sey, N. - SzÁmadó, E. - VIDA, I.: Jelentés a Komárom-Szőny, Vásártéren 2012-ben folytatott régészeti feltárások eredményeiről - Bericht über die Ergebnisse der im Jahre 2012 in Brigetio (FO: Komárom/Szőny, Vásártér) geführten archäologischen Ausgrabungen. Kuny Domokos Múzeum Közleményei 20 (2014) 62-64.

SzórÁdi Zs.: Terra sigillata leletek. In: Bartus, D. - Borhy, L. - Delbó G. - Dévai K. - Kis Z. Nagy A. - Sey N. - Számadó E. - Szórádi Zs. - Vida I.: Jelentés a Komárom-Szőny, Vásártéren 2011-ben folytatott régészeti feltárások eredményeiről - Bericht über die Ergebnisse der im Jahre 2011 in Brigetio (FO: Komárom/Szőny, Vásártér) geführten archäologischen Ausgrabungen. Kuny Domokos Múzeum Közleményei 19 (2013) [2014] 35-57.

Vida, I.: Éremleletek. In: Bartus, D. - Borhy, L. - Delbó, G. - Dévai, K. - Kis, Z. - Nagy, A. - Sey, N. - SzÁmAdó, E. - SzóRÁdI, Zs. - VIDA, I.: Jelentés a Komárom-Szőny, Vásártéren 2011-ben folytatott régészeti feltárások eredményeiről - Bericht über die Ergebnisse der im Jahre 2011 in Brigetio (FO: Komárom/Szőny, Vásártér) geführten archäologischen Ausgrabungen. Kuny Domokos Múzeum Közleményei 19 (2013) [2014] 59-61. 
Vida, I.: Éremleletek. In: Bartus, D. - Borhy, L. - Delbó, G. - Dévai, K. - Kis, Z. - Nagy, A. - Sey, N. - SzÁmadó, E. - VIDA, I.: Jelentés a Komárom-Szőny, Vásártéren 2012-ben folytatott régészeti feltárások eredményeiről - Bericht über die Ergebnisse der im Jahre 2012 in Brigetio (FO: Komárom/Szőny, Vásártér) geführten archäologischen Ausgrabungen. Kuny Domokos Múzeum Közleményei 20 (2014) 64-65.

\section{3}

Borhy, L. - BARTus, D. - SzÁmadó, E.: Short report on the excavations at Brigetio (Szőny-Vásártér) in 2013. Dissertationes Archaeologicae Ser. 3. No. 1 (2013) 129-140.

Bonsos, A: Római kori csontfaragványok Brigetióból (2003-2011). Unpublished BA-thesis. Budapest 2013.

DÁlNoKI, O.: Brigetio Komárom-Szőny Vásártér 2013. Római kori pince (LM 16-17) földanyagából nyert növényminták mennyiségi és minőségi elemzése. Glis 2013 (Manuscript).

Hajdu, B.: A Szőny-Vásártéren 2009-ben feltárt római kori pince kerámiaanyaga (kivéve terra sigillata). Unpublished BA-thesis. Budapest 2013.

HuszTA, H.: Római kori mécsesek a Szőny-Vásártér lelőhelyről (2003-2012). Unpublished BA-thesis. Budapest 2013.

PÁsztókai-Szeőke, J. - PAetz gen. Schieck, A.: Inspiráció, imitáció és imázs. A Kr. u. 3. századi katonai viselet szír eredetű elemei. Ókor 2013, 61-68.

PÁsztókai-Szeőke, J. - Paetz gen. Schieck, A.: Power Dressing in Pannonia. Tunics with ArrowShaped Purple Decoration Represented in a Roman Wall-Painting at Brigetio. In: Alfaro Giner, C. - Ortiz García, J. - Martínez García, M. J. (eds.): Luxury and Dress. Political Power and Appearence in the Roman Empire and its Provinces. Valencia 2013, 181-216.

SEY, N.: A pannoniai római kori bronzmúvesség mühelykérdései. Unpublished PhD-thesis. Budapest 2013.

\section{2}

Bartus, D. - Borhy, L. - Dévai, K. - Kis, Z. - Nagy, A. - Sey, N. - Számadó, E. - Szórádi, Zs. VIDA, I.: Jelentés a Komárom-Szőny, Vásártéren 2010-ben folytatott régészeti feltárások eredményeiről. Komárom-Esztergom Megyei Múzeumok Közleményei 18 (2012) 7-57.

Borhy, L.: Die legio XI Claudia im pannonischen Brigetio (Komárom/Szőny, Ungarn). In: KovÁcs, P. - FeHÉr, B. (eds.): In memoriam Barnabás Lórincz. Studia Epigraphica Pannonica 4. Budapest 2012, 23-36.

Borhy, L.: Hinweise auf Schifffahrt und Fernhandel in Brigetio, Komárom/Szőny, Ungarn). Histria Antiqua 21 (2012) 37-48.

Borhy, L.: COREG, Legio VII Claudia, Ala I Contariorum milliaria civium Romanorum - Neue Angaben zur Militärgeschichte von Brigetio: Spolien eines Steinkistengrabs aus dem Gerhát-Gräberfeld. In: Borhy, L. (ed.): Studia Celtica Classica et Romana Nicolae Szabó septuagesimo dedicata. Budapest 2012, 65-77.

Borhy, L.: Bélyeges téglák. In: Bartus, D. - Borhy, L. - Dévai, K. - Kis, Z. - Nagy, A. - Sey, N. SzÁmADó, E. - SzóRÁdi, Zs. - VIDA, I.: Jelentés a Komárom-Szőny, Vásártéren 2010-ben folytatott régészeti feltárások eredményeiről. Komárom-Esztergom Megyei Múzeumok Közleményei 18 (2012) 9-11. 
Borhy, L. - Bartus, D. - SzÁmadó, E.: A régészeti feltárás eredményei. In: BArtus, D. - Borhy, L. Dévai, K. - Kis, Z. - Nagy, A. - Sey, N. - SzÁmadó, E. - SzórÁdi, Zs. - VidA, I.: Jelentés a Komárom-Szőny, Vásártéren 2010-ben folytatott régészeti feltárások eredményeiről. Komárom-Esztergom Megyei Múzeumok Közleményei 18 (2012) 7-8.

Borhy, L. - SzÁmadó, E.: Komárom-Szőny, Vásártér. In: Régészeti kutatások Magyarországon 2010 Archaeological Investigations in Hungary 2010. Budapest 2012, 264-265.

Borhy, L. - SzÁmadó, E. - DévaI, K.: Komárom, Műszerész utca. In: Régészeti kutatások Magyarországon 2010 - Archaeological Investigations in Hungary 2010. Budapest 2012, 263.

Borhy, L. - SzÁmadó, E. - DévaI, K.: Komárom, Mártírok útja. In: Régészeti kutatások Magyarországon 2010 - Archaeological Investigations in Hungary 2010. Budapest 2012, 263-264.

Borhy, L. - SzÁmadó, E. - DévaI, K. - Sey, N.: Komárom-Szőny, MOL-bázistelep. In: Régészeti kutatások Magyarországon 2010 - Archaeological Investigations in Hungary 2010. Budapest 2012, 263-264.

Dévai, K.: Üvegleletek. In: Bartus, D. - Borhy, L. - Dévai, K. - Kis, Z. - Nagy, A. - Sey, N. - SzÁmadó, E. - SzóRÁDI, Zs. - VIDA, I.: Jelentés a Komárom-Szőny, Vásártéren 2010-ben folytatott régészeti feltárások eredményeiről. Komárom-Esztergom Megyei Múzeumok Közleményei 18 (2012) 11-21.

DÉvaI, K. - Gelencsér, Á.: Római kori lakóház és üveggyártó műhely Brigetióban. In: Bíró, Sz.VÁmos, P. (ed.): FIRKÁK II. Fiatal Római Koros Kutatók II. Konferenciakötete. Győr 2012, 439-468.

Dévai, K. - Gelencsér, Á.: Római kori lakóépület és üvegműhely Brigetióból. Komárom-Esztergom Megyei Múzeumok Közleményei 18 (2012) 59-102.

FóRIZs, I. - NAGY, G. - DÉVAI, K.: Brigetiói üvegleletek műszeres analitikai vizsgálata. In: BíRó Sz. VÁmos P. (ed.): FIRKÁK II. Fiatal Római Koros Kutatók II. Konferenciakötete. Győr 2012, 469476.

FóRIzs, I. - DÉvAI, K. - TóTH, M. - NAGY, G. - MAY, Z.: A brigetiói üveggyártó műhely néhány jellemző üvegleletének műszeres analitikai vizsgálata. Komárom-Esztergom Megyei Múzeumok Közleményei 18 (2012) 103-114.

HarsÁnyi, E. - Kurovszky, Zs.: Előzetes beszámoló a Komárom/Szőny, Vásártér 2. szám alatti családi háznál feltárt római kori falfestményekről. In: Bíró, Sz.-VÁmos, P. (ed.): FIRKÁK II. Fiatal Római Koros Kutatók II. Konferenciakötete. Győr 2012, 477-491.

Kis, Z.: Import- és helyi kerámia. In: Bartus, D. - Borhy, L. - Dévai, K. - Kis, Z. - Nagy, A. - Sey, N. - SzÁmAdó, E. - SzóRÁdi, Zs. - VIDA, I.: Jelentés a Komárom-Szőny, Vásártéren 2010-ben folytatott régészeti feltárások eredményeiről. Komárom-Esztergom Megyei Múzeumok Közleményei 18 (2012) 21-23.

Nagy, A.: Amphorák. In: Bartus, D. - Borhy, L. - Dévai, K. - Kis, Z. - Nagy, A. - Sey, N. - SzÁmadó, E. - SzóRÁDI, Zs. - VIDA, I.: Jelentés a Komárom-Szőny, Vásártéren 2010-ben folytatott régészeti feltárások eredményeiről. Komárom-Esztergom Megyei Múzeumok Közleményei 18 (2012) 24-28; $53-54$.

Sey, N.: Bronztárgyak. In: Bartus, D. - Borhy, L. - Dévai, K. - Kis, Z. - Nagy, A. - Sey, N. - Számadó, E. - SzÓRÁDI, Zs. - VIDA, I.: Jelentés a Komárom-Szőny, Vásártéren 2010-ben folytatott régészeti feltárások eredményeiről. Komárom-Esztergom Megyei Múzeumok Közleményei 18 (2012) 31-33.

SzórÁdi, Zs.: Terra sigillata leletek. In: Bartus, D. - Borhy, L. - DÉvaI, K. - Kis, Z. - NAgy, A. SEY, N. - SzÁmAdó, E. - SzóRÁdi, Zs. - VIDA, I.: Jelentés a Komárom-Szőny, Vásártéren 2010ben folytatott régészeti feltárások eredményeiről. Komárom-Esztergom Megyei Múzeumok Közleményei 18 (2012) 29-31. 
Vida, I.: Éremleletek. In: Bartus, D. - Borhy, L. - Dévai, K. - Kis, Z. - Nagy, A. - Sey, N. - SzÁmadó, E. - SzóRÁDI, Zs. - VIDA, I.: Jelentés a Komárom-Szőny, Vásártéren 2010-ben folytatott régészeti feltárások eredményeiről. Komárom-Esztergom Megyei Múzeumok Közleményei 18 (2012) 34-35.

\section{1}

BARTUs, D.: Roman figural bronzes from Brigetio: preliminary notes. In: NovotnÁ, M. et al. (eds.) The phenomena of cultural borders and border cultures across the passage of time (From the Bronze Age to Late Antiquity). Anodos. Studies of the Ancient World 10 (2010). Trnava 2011, 17-28.

BORHy, L.: “Aurelius Iulianus beneficiarius praesidis perfectissimi viris (!)”. Megjegyzések egy brigetiói oltár feliratához (CIL III 4301). In: FeHÉr, B. - Kovács, P. (eds.): Studia Epigraphica Pannonica 3. Budapest 2011, 39-45.

Borhy, L. - DÉvaI, K. - SzÁmadó, E.: Komárom-Szőny, Mártírok útja (Lidl áruház építése). KomáromEsztergom Megyei Múzeumok Közleményei 17 (2011) 274.

DeLBó, G.: Brigetio fazekasipara. Unpublished MA-thesis. Budapest 2011.

DÉvAI, K.: A Komárom/Szőny-vásártéri ásatások római kori üvegleletei. Komárom-Esztergom Megyei Múzeumok Közleményei 17 (2011) 133-150.

Doвоsi, L.: Városi lakóházépitészet Brigetióban. A Komárom/Szőny-Vásártér lelóhelyen 1992-2010 között folytatott ásatások épitészeti vonatkozású eredményei. Unpublished MA-thesis. Budapest 2011.

Dobosi, L. - Borhy, L.: The Municipium of Brigetio. Roman Houses at Komárom/Szőny-Vásártér. Periodica Polytechnica Architecture 42.2 (2011) 3-10.

\section{0}

Bartus, D.: (Rec.) Borhy L. - Harsányi E. - Kovács L. O. - Kurovszky Zs. - Magyar M. - A. Paetz Pásztókai Szeőke J. - Számadó E.: Római kori falfestmények Brigetióból. A komáromi Klapka György Múzeum római kori falfestményeinek katalógusa. Acta Archaeologica Brigetionensia Ser. I. Vol. 3. Komárom 2010. In: Dezső, T. (ed.): 375. Történelem és régészet az Eötvös Loránd Tudományegyetem Bölcsészettudományi Karán. Budapest 2010, 16-17.

Borhy, L. - Harsányi, E. - Kovács, L. O. - Kurovszky, Zs. - Magyar, M. - Paetz gen. Schieck, A. PÁszTóKai-Szeőke, J. - SzÁmadó, E.: Római kori falfestmények Brigetióból. A komáromi Klapka György Múzeum katalógusai XIV. Acta Archaeologica Brigetionensia Ser. I. Vol. 3. Komárom 2010.

Borhy, L. - SzÁmadó, E. - DévaI, K.: Komárom-Szőny, Mártírok útja. In: Régészeti kutatások Magyarországon 2009 - Archaeological Investigations in Hungary 2009. Budapest 2010, 248-249.

Borhy, L. - SzÁmadó, E.: Komárom-Szőny, Szabadság út. In: Régészeti kutatások Magyarországon 2009 - Archaeological Investigations in Hungary 2009. Budapest 2010, 249.

BorHy, L. - SzÁmadó, E.: Komárom-Szőny, Vásártér. In: Régészeti kutatások Magyarországon 2009 - Archaeological Investigations in Hungary 2009. Budapest 2010, 250-251.

KIs, Z.: Római kori tárgyak a komáromi Bodor-gyújteményből. Unpublished BA-thesis. Budapest 2010.

SzóRÁDI, Zs.: Terra sigillata leletek a Brigetio-Vásártéren 2009-ben feltárt pincéböl. Unpublished BAthesis. Budapest 2010. 


\section{9}

BARTus, D.: Római kori csont kardszíjbújtató Brigetióból. In: BARTosiewicz, L. et al. (eds.): Csontvázak a szekrénybőll. Válogatott tanulmányok a Magyar Archaeozoológusok Visegrádi Találkozóinak anyagából 2002-2009. Budapest 2009, 211-220.

BORHY, L.: Brigetiói amphitheatrumok? Budapest 2009.

Borhy, L.: Tempus és universum ábrázolások az ókori művészetben. In: ANDERs, A. - RACzKy, P. SzABó, M. (eds.): Régészeti dimenziók. Tanulmányok az ELTE BTK Régészettudományi Intézetének tudományos mühelyéből. A 2008. évi Magyar Tudomány Ünnepe keretében elhangzott előadások. Budapest 2009, 61-74.

Borhy, L. - SzÁmAdó, E.: Komárom-Szőny, Vásártér. In: Régészeti kutatások Magyarországon 2008 Archaeological Investigations in Hungary 2008. Budapest 2009, 216-217.

\section{8}

BorHy, L. - SzÁmADó, E.: Komárom-Szőny, MOLAJ, Kőolaj u. 2. In: Régészeti kutatások Magyarországon 2007 - Archaeological Investigations in Hungary 2007. Budapest 2008, 237.

Borhy, L. - SzÁmadó, E.: Komárom-Szőny, Vásártér. In: Régészeti kutatások Magyarországon 2007 Archaeological Investigations in Hungary 2007. Budapest 2008, 238-239.

Borhy, L. - SzÁmadó, E. - Bartus, D. - Gelencsér, Á. - Cseh, J.: Újabb késő római kőládasír Brigetio Gerhát-temetőjéből. In: Régészeti kutatások Magyarországon 2007 - Archaeological Investigations in Hungary 2007. Budapest 2008, 5-18.

\section{$\mathbf{2 0 0 7}$}

Borhy, L.: Par domus est caelo. A tér- és időszimbolika elemei a római császárkori boltozat és kupoladíszitó múvészetben. Budapest 2007.

BorHy, L.: Instrumenta scripta Latina et Graeca aus Brigetio: Gemmen und Ringe mit lateinischen und griechischen Inschriften. In: MAYER, M. et al. (eds.): Acta XII Congressus Internationalis Epigraphiae Graecae et Latinae. Barcelona 2007, 185-190.

BoRHY, L.: Műemléki tervek Brigetio "Vásártéri” maradványainak bemutatására. Örökség 11.7-8 (2007) 7.

BORHy, L.: Calçotada im römischen Pannonien? Interpretation eines Wandgemäldes aus Brigetio (FO: Komárom/Szőny-Vásártér, Ungarn). In: Guiral Pelegrín, C. (ed.): Circulación de temas y sistemas decorativos en la pintura mural antigua. Actas del IX Congreso Internacional de la Association Internationale pour la Peinture Murale Antique (AIPMA), Zaragoza - Calatayud 2125 septiembre 2004. Zaragoza 2007, 263-265.

BORHY, L. - SzÁmAdó, E.: Komárom-Szőny, Vásártér. In: Régészeti kutatások Magyarországon 2006 Archaeological Investigations in Hungary 2006. Budapest 2007, 217-219.

BorHy, L. - SzÁmadó, E.: Feliratok egy késő római kőládasírból a brigetiói Gerhát temetőből. In: KovÁcs, P. - Szabó, Á. (eds.): Studia Epigraphica Pannonica, Vol. I. Észak-Kelet Pannonia 1. Budapest 2007, $115-132$. 
DÉVAI, K: A Komárom/Szőny-Vásártéri ásatások római kori üvegleletei (1992-2005). Unpublished MAthesis. Budapest, 2007.

Harsányi, E. - Kurovszky, Zs. - Kovács, L. O.: First Resoults of the Restitution of a Wall-painting from a Peristyle in Brigetio at Site Civil Town II. In: Guiral Pelegrín, C. (ed.): Circulación de temas y sistemas decorativos en la pintura mural antigua. Actas del IX Congreso Internacional de la Association Internationale pour la Peinture Murale Antique (AIPMA), Zaragoza - Calatayud 21-25 septiembre 2004. Zaragoza 2007, 407-410.

SzÁMADó, E.: Komárom-Szőny, Vásártér. In: Régészeti kutatások Magyarországon 2006 - Archaeological Investigations in Hungary 2006. Budapest 2007, 219-220.

TőKÉs, T.: A Komárom/Szőny-Vásártéri ásatások római kori import kerámialeletei (2001-2005). Unpublished MA-thesis. Budapest, 2007.

\section{6}

BARTus, D.: Aranyfejű csont hajtűk a római korban. Archaeologiai Értesitó 131 (2006) 193-203.

Bartus, D.: Roman bone scabbard slide from Brigetio. In: Novotná, M. et al. (eds.): Arms and Armour through the Ages (from the Bronze Age to the Late Antiquity). Anodos. Studies of Ancient World 4-5 (2004-2005). Trnava 2006, 17-23.

Borhy, L.: Vezetó Komárom város római kori kőemlékeihez. Acta Archaeologica Brigetionensia Ser. I. Vol. 5., Komárom 2006.

Borhy, L.: IEPO $\Sigma$ ГAMO $\Sigma$. Überlegungen zu einer griechischen Münze aus Brigetio. Acta Archaeologica Academiae Scientiarum Hungaricae 57 (2006) 225-233.

Borhy, L.: Roman Wall Paintings from Brigetio, Hungary. Minerva. The International Review of Ancient Art and Archaeology 17.5. (2006) 30-32.

Borhy, L.: Brigetio/Komárom-Szőny, Komárno. In: Humer, F. (ed.): Legionslager und Druidenstab. Vom Legionslager zur Donaumetropole. Sonderausstellung aus Anlass des fubiläums "2000 fahre Carnuntum”. Wien - Carnuntum 2006, 152-153.

Borhy, L.: Brigetio. Rzymskie miasto w Panonii w świetle badań archeologicznych. Xenia Posnanensia, series altera 27. Poznań 2006.

Borhy, L.: Kozmikus és földi archeológia. Természet Világa 137.12 (2006) 542-544.

BoRHy, L.: Ein eiserner Helm aus Brigetio (FO: Komárom/Szőny-Vásártér, Ungarn). In: NovotnÁ, M. et al. (eds.): Arms and Armour through the Ages (from the Bronze Age to the Late Antiquity). Anodos. Studies of Ancient World 4-5 (2004-2005). Trnava 2006, 35-38.

Borhy, L. - SzÁmadó, E.: Komárom, Szőny, Vásártér. In: Régészeti kutatások Magyarországon 2005 Archaeological Investigations in Hungary 2005. Budapest 2006, 261-262.

RupNik, L.: Római kori vastárgyak Brigetióból (Komárom/Szőny-Vásártér, 1992-2005). Unpublished MA-thesis. Budapest 2006.

SEY, N.: Római kori bronztárgyak Brigetióból (Komárom/Szőny-Vásártér, 1992-2005). Unpublished MA-thesis. Budapest 2006.

\section{5}

Borhy, L.: Ganz nach römischem Geschmack. Neuentdeckte Wandmalereien aus der einst blühenden Legionsstadt Brigetio am nordöstlichen Limes (Komárom/Szőny, Ungarn). Antike Welt 36.4 (2005) 51-56. 
Borhy, L.: Zwischen Antike und Gegenwart: Zwei Ziegelgraffiti aus Brigetio. In: Dobiat, C. (ed.): RELIQUIAE GENTIUM. Festschrift für Horst Wolfgang Böhme, Teil I. Rahden/Westf. 2005, 75-77.

BoRHy, L.: Instrumenta inscripta Latina aus Brigetio (FO: Komárom/Szőny-Vásártér). Grabungskampagnen 1992-1997. Sylloge Epigraphica Barcinonensis 10 (2005) 99-147.

BorHy, L.: Militaria aus der Zivilstadt von Brigetio (FO: Komárom/Szőny-Vásártér). Indirekte und direkte militärische Hinweise auf Beginn, Dauer und Ende der Zivilsiedlung im Lichte der neuesten Ausgrabungen (1992-2004). In: Borhy, L. - Zsidi, P. (eds.): Die norisch-pannonischen Städte und das römische Heer im Lichte der neusten archäologischen Forschungen. II. Internationale Konferenz über norisch-pannonische Städte. Budapest, 2002. szeptember 11-14. Aquincum Nostrum II.3., Budapest 2005, 73-79.

Borhy, L. - SzÁmadó, E.: Komárom, Szőny, Vásártér. In: Régészeti kutatások Magyarországon 2004 Archaeological Investigations in Hungary 2004. Budapest 2005, 238-240.

Borhy, L. - SzÁmadó, E.: Leletek a kútban. Élet és Tudomány 60.5 (2005) 148-150.

Borhy, L. - SzÁmadó, E.: A szamoszi Héra. Egy görög istennő Pannoniában. Élet és Tudomány 60.17 (2005) 522-524.

Borhy, L. - SzÁmAdó, E.: Brigetiói amphitheatrumok? Egy latin felirat tanulságai. Élet és Tudomány $60.31(2005)$ 970-973.

VANDlik, K.: Aisopica: Eine Silbergemme aus Brigetio. Archäologisches Korrespondenzblatt 35 (2005) 397-403.

\section{4}

BARTus, D.: Bone hairpins from Brigetio. In: NovotnÁ, M. et al. (eds.): Schmuck und Tracht der Antike im Laufe der Zeit (Seit der Spätbronzezeit bis zur Spätantike). Proceedings of the International Conference. Modra-Harmónia, 19.-22.11.2003. Anodos. Studies of the Ancient World 3 (2003). Trnava 2004, 23-32.

BARTUS, D.: Adatok a brigetiói csontfaragó mủhely lokalizálásához. Komárom-Esztergom Megyei Múzeumok Közleményei 10 (2004) 55-75.

BEcK, T.: Brigetiói terra sigillaták (1992-1996). Unpublished PhD-thesis. Budapest 2004.

Borhy, L.: Horae, Andromeda und Pegasos: Die Kosmologie des Deckengemäldes aus Brigetio (FO: Komárom/Szőny-Vásártér). In: Borhy, L. (ed.), Plafonds et voûtes à l'époque antique. Actes du VIIIe Colloque international de l'Association Internationale pour la Peinture Murale Antique (AIPMA), 15-19 mai 2001, Budapest - Veszprém. Budapest 2004, 233-244.

Borhy, L.: Ewige Zeit - Ewiges Leben: Das Deckengemälde aus Brigetio und das kosmologische Zimmer des Cosmas Indicopleustes. In: Gourdouba, M. - Pietilä-Castrén, L. - Tikkala, E. (eds.): The Eastern Mediterranean in the late antique and early Byzantine periods. Papers and Monographs of the Finnish Institue at Athens, Vol. IX. Helsinki 2004, 1-16.

Borhy, L.: Der illusionistische Oculus auf dem Deckengemälde aus Brigetio und das kosmologische Zimmer des Cosmas Indicopleustes. Acta Antiqua Academiae Scientiarum Hungaricae 44 (2004) 305-316.

BorHy, L.: A brigetiói mennyezetfestmény I. Élet és Tudomány 59.16 (2004) 488-502.

BoRHy, L.: A brigetiói mennyezetfestmény II. Élet és Tudomány 59.17 (2004) 528-532. 
BoRHy, L.: Brigetio. Ergebnisse der 1992-1998 durchgeführten Ausgrabungen (Munizipium, Legionslager, Canabae, Gräberfelder). In: ŠAšEL Kos, M. - Scherrer, P. (eds.): The Autonomous Towns of Noricum and Pannonia - Die autonomen Städte in Noricum und Pannonien. Pannonia II. Situla 42. Lubljana 2004, 231-251.

Borhy, L. - SzÁmadó, E.: Csillagok és lakoma. Falfestmények a római kori Brigetióból. Magyar Múzeum 10.3 (2004) 17-19.

Borhy, L. - SzÁmadó, E.: Komárom, Szőny, Vásártér. In: Régészeti kutatások Magyarországon 2003 Archaeological Investigations in Hungary 2003. Budapest 2004, 243-244.

Harsányi, E. - Kurovszky, Zs.: Traces of Geometric Constructions on the Second Century A.D. Roman Ceiling Composition of Komárom/Szőny-Vásártér. In: Borhy, L. (ed.): Plafonds et voûtes à l'époque antique. Actes du VIIIe Colloque international de l'Association Internationale pour la Peinture Murale Antique (AIPMA), 15-19 mai 2001, Budapest-Veszprém. Budapest 2004, 245253.

HÁrshegyi, P.: Roman Amphorae from the Civil Town of Brigetio / Szőny-Vásártér 1992-2001. Communicationes Archaeologicae Hungariae 2004, 112-121.

VANDLIK, K.: Aesopica. Ezüstgemma Brigetióból. Antik Tanulmányok 48 (2004) 135-142.

\section{3}

BARTus, D.: Római kori csontfaragványok a komáromi Klapka György Múzeumban. Unpublished MAthesis. Budapest 2003.

Borhy, L.: Brigetio. In: Visy, Zs. (ed.): Magyar régészet az ezredfordulón. Budapest 2003, 22-23.

Borhy, L. - SzÁmadó, E.: Gemmák, gemmás gyürük és ékszerek Brigetióban. A komáromi Klapka György Múzeum katalógusai IV. Acta Archaeologica Brigetionensia Ser. I. Vol. 4., Komárom 2003.

Borhy, L. - SzÁmAdó, E.: Falfestmény Brigetióban. Csemege egy római lakomán. Élet és Tudomány 58.31 (2003) 976-978.

Borhy, L. - SzÁmadó, E.: Apró istenek és istennő. Gemmák Brigetióból. Élet és Tudomány 58.22 (2003) 688-690.

Borhy, L. - SzÁmadó, E.: Falfestmény Brigetióban. Csemege egy római lakomán. Élet és Tudomány 58.31 (2003) 976-978.

Borhy, L. - SzÁmadó, E.: Brigetio, castra legionis. In: Visy, Zs. (ed.): The Roman Army in Pannonia. An Archaeological Guide of the Ripa Pannonica. Pécs 2003, 75-77.

Borhy, L. - SzÁmadó, E.: Brigetio, Temporary Camps. In: Visy, Zs. (ed.): The Roman Army in Pannonia. An Archaeological Guide of the Ripa Pannonica. Pécs 2003, 78-79.

Borhy, L.-SzÁmadó, E.: Komárom, Szőny, Vásártér 2. In: Régészeti kutatások Magyarországon 2001 Archaeological Investigations in Hungary 2001. Budapest 2003, 179-180.

BoRHy, L.-SzÁmadó, E.: Komárom, Szőny, Vásártér. In: Régészeti kutatások Magyarországon 2003 Archaeological Investigations in Hungary 2002. Budapest 2003, 228-229.

Borhy, L. - Kuzmová, K. - RajtÁr, J. - SzÁmadó, E.: Kelemantia - Brigetio. Auf den Spuren der Römer an der Donau. Wegweiser. Komárno 2003.

Borhy, L. - Kuzmová, K. - RajtÁr, J. - SzÁmadó, E.: Kelemantia - Brigetio. Tracing the Romans on the Danube. Guide. Komárno 2003. 
FÉNYes, G.: Az import kerámia Brigetióban és hatása a helyi fazekasságra. Unpublished PhD-thesis. Budapest 2003.

\section{2}

Borhy, L.: Faustina minor como diosa de la belleza y patrona de la maternidad. In: Marco Simón, F. - Pina Polo, F. - Remesal Rodríguez, J. (eds.): Religión y política propaganda en el mondo romano. Collecció Instrumenta 12. Barcelona 2002, 137-142.

Borhy, L.: Die Personifikationen der Vier Jahreszeiten (Horae) auf dem römischen Deckengemälde von Brigetio/Vásártér. In: Kuzmová, K. (ed.): In Honour of Mária Novotná. Anodos. Studies of Ancient World 2. Trnava 2002, 41-51.

Borhy, L.: Alea falsa est? Gedanken zu einem trügerischen Würfel aus Brigetio. In: Kuzmová, K. Pieta, K. - RAjtÁR, J. (eds.): Zwischen Rom und dem Barbaricum. Festschrift für Titus Kolník zum 70. Geburtstag. Archaeologica Slovaca Monographiae. Communicationes Instituti Archaeologici Nitriensis Academiae Scientiarum Slovacae, Tomus V. Nitra 2002, 55-58.

FÉnyes, G.: A Brigetióban előkerült bélyeges mécsesek. Communicationes Archaeologicae Hungariae 2002, 59-91.

Harsányi, E. - Kurovszky, Zs.: Traces of Geometric Constructions on the Second Century A.D. Roman Ceiling Composition of Szőny. Acta Archaeologica Academiae Scientiarum Hungaricae 53 (2002) 151-169.

Harsányi, E. - Kunovszky, Zs.: Komárom/Szőny-Brigetio, Vásártér 2. Leletmentés során feltárt falfestmények restaurálása. Múemlékvédelmi Szemle 2002/2, 55-57.

\section{$\mathbf{2 0 0 1}$}

BARTus, D.: Csontfaragó műhely Brigetióban? - Az 1999-2000-ben feltárt faragott csonttárgyak katalógusa (Kat. 54-162.). In: BoRHY, L. (ed.): Római kori csontfaragványok és modern hamisítványok. Csontfaragómúvészet Brigetióban. Acta Archaeologica Brigetionensia Ser. I. Vol. 2. Komárom 2001, 28-54.

Borhy, L.: Pannoniai falfestmény. A Négy Évszak, az idó és a Csillagok ábrázolása egy brigetiói mennyezetfestményen. Budapest 2001.

Borhy, L. (ed.): A római kori falfestészet Pannoniában. Nemzetközi konferencia a pannoniai falfestészet problémáiról. Komárom, 1998. május 2. - Die römische Wandmalerei in Pannonien. Internationale Fachkonferenz über Probleme der Wandmalerei in Pannonien. Komárom, den 2. Mai 1998. Acta Archaeologica Brigetionensia Ser. I. Vol. 1. Budapest - Komárom 2001.

Borhy, L. (ed.): Római kori csontfaragványok és modern hamisitványok. Csontfaragómúvészet Brigetióban. Acta Archaeologica Brigetionensia Ser. I. Vol. 2., Komárom 2001.

Borhy, L.: Die Kosmologie des Deckengemäldes aus Brigetio (FO: Komárom/Szőny-Vásártér. In: Borhy, L. (ed.): Plafonds et voûtes a l'époque antique. Résumes du VIIIe Colloque International de l'Association Internationale pour la Peinture Murale Antique (Budapest-Veszprém, 15-19 mai 2001). Budapest 2001, 9-10.

Borhy, L.: A szőnyi leletekről - helyesen! Természet Világa 132.3 (2001) 142.

Borhy, L.: Hellenistische Kosmologie auf einem provinzialrömischen Deckengemälde aus Brigetio (FO: Komárom/Szőny-Vásártér, Ungarn). Anodos. Studies of Ancient World 1 (2001) 27-31. 
BoRHy, L.: Neues zur Tätigkeit und zu den Vorbildern der modernen Fälscherwerkstatt in Brigetio (Komárom/Szőny, Ungarn). In: Zsidi, P. (ed.): Akten des 6. Internationalen Kolloquiums über Probleme des provinzialrömischen Kunstschaffens, Historisches Museum der Stadt Budapest, 1116. Mai 1999. Budapest Régiségei 34. Budapest 2001, 29-37.

Borhy, L.: Le décor des édifices publics et privés: peintures murales et mosadques. In: FAcsÁdy, A. (ed.): Romains de Hongrie. Ier-Ve siecles après f.-C. Exposition produite par le Département du Rhône, Musée de la Civilisation gallo-romaine de Lyon en collaboration avec le Musée Historique de Budapest dans le cadre de la Saison hongroise en France. Musée de la Civilisation, Lyon, décembre 2001 - mai 2002. Lyon - Budapest 2001, 88-96.

Borhy, L.: Komárom-Szőny, Brigetio. Polgárváros és temető. In: Raczky, P. - ANDERs, A. - KovÁcs, T. (eds.): Régészetünk jelentős feltárásai 1975-2000. Budapest 2001, 16.

BorHy, L.: A szőnyi csont- és kőfaragványokat hamisító műhely (Kat. 165-166.). In: BorHy, L. (ed.): Római kori csontfaragványok és modern hamisitványok. Csontfaragómüvészet Brigetióban. Acta Archaeologica Brigetionensia Ser. I. Vol. 2. Komárom 2001, 58-66.

BorHy, L.: Római kori érmek Brigetióból. 2001. évi naptár, Komárom Város Önkormányzatának reprezentatív kiadványa. Komárom 2001.

Borhy, L. - SzÁmadó, E.: A Komárom (Szőny-Vásártér) lelőhelyen 2001-ben folytatott régészeti feltárásokról. Komáromi Ujsság 11.12 (2001) 1-2.

Borhy, L. - SzÁmadó, E.: A Komárom/Szőny-Vásártér lelőhelyen 2001-ben folytatott régészeti feltárások eredményei. Komáromi Újság 11.13 (2001) 1, 4.

Borhy, L. - SzÁmadó, E.: A Komárom/Szőny-Vásártér lelőhelyen 2001-ben folytatott régészeti feltárások eredményei (2. rész). Komáromi Újság 11.13 (2001) 4.

Borhy, L. - SzÁmAdó, E.: Brigetiói vadállatok. A Komárom/Szőny Vásártér 2. sz. alatt feltárt római kori falfestményekről. Atelier 2001.4, 46-47.

BorHy, L. - SzÁMAdó, E.: Beszámoló a Komárom/Szőny Vásártér 2. számú háznál 1999-2001 folyamán végzett feltárásokról. Komárom-Esztergom Megyei Múzeumok Közleményei 8 (2001) 83-104.

Borhy, L. - Kuzmová, K. - RajtáR, J. - SzÁmadó, E.: Kelemantia - Brigetio. A rómaiak nyomában a Duna mentén. Útikalauz. Komárno 2001.

Borhy, L. - Kuzmová, K. - RajtáR, J. - SzÁmadó, E.: Kelemantia - Brigetio. Po stopách Rimanov na Dunaji. Sprievodca. Komárno 2001.

Borhy, L. - Kuzmová, K. - RajtáR, J. - SzÁmadó, E.: Kelemantia - Brigetio. Auf den Spuren der Römer an der Donau. Wegweiser. Komárno 2001.

Borhy, L. - Kuzmová, K. - Rajtár, J. - SzÁmadó, E.: Kelemantia - Brigetio. Tracing the Romans on the Danube. Guide. Komárno 2001.

FÉNYES, G.: Adatok a brigetiói municipium kereskedelmi életéhez (A csontfaragó mühely (?) kerámiaanyagának kiértékelése. In: BorHy, L. (ed.): Római kori csontfaragványok és modern hamisítványok. Csontfaragómúvészet Brigetióban. Acta Archaeologica Brigetionensia Ser. I. Vol. 2. Komárom 2001, 67-69.

HARsÁNYI, E. - KuRovsZKY, Zs.: Antike geometrische Werkzeichnungen auf dem Deckengemälde von Brigetio (Komárom/Szőny-Vásártér). In: Borhy, L. (ed.): Plafonds et voûtes à l'époque antique. Résumes du VIIIe Colloque International de l'Association Internationale pour la Peinture Murale Antique (Budapest-Veszprém, 15-19 mai 2001). Budapest 2001, 16-17.

Magyar, M. V.: Római kori festett falképek Brigetio Polgárvárosából, az I. sz. házból. Upublished MAthesis. Budapest 2001. 
Mikцósity Szőke, M.: Szarvasagancsból készült tárgyak Brigetióból. In: BoRHy, L. (ed.): Római kori csontfaragványok és modern hamisitványok. Csontfaragómúvészet Brigetióban. Acta Archaeologica Brigetionensia Ser. I. Vol. 2. Komárom 2001, 55-57.

MikLósity SzőKe, M. - BARTosiewicz, L.: Két szarvasagancs amulett Brigetio polgárvárosából; Római kori gímszarvasagancs rózsatövének biometriai elemzése. Komárom-Esztergom Megyei Múzeumok Közleményei 8 (2001) 105-132.

PÁszTóKaI-SzeőKe, J.: A Brigetióban, Komárom/Szőny-Vásártér lelőhelyen 1992-1999 között feltárt faragott csonttárgyak katalógusa (Kat. 1-53.). In: BoRHY, L. (ed.): Római kori csontfaragványok és modern hamisitványok. Csontfaragómüvészet Brigetióban. Acta Archaeologica Brigetionensia Ser. I. Vol. 2. Komárom 2001, 9-27.

\section{0}

Bíró, E.: Falfestmények Brigetio canabaejából - Wandmalereien aus den canabae von Brigetio. In: Borhy, L. (ed.): A római kori falfestészet Pannoniában. Nemzetközi konferencia a pannoniai falfestészet problémáiról. Komárom, 1998. május 2. - Die römische Wandmalerei in Pannonien. Internationale Fachkonferenz über Probleme der Wandmalerei in Pannonien. Komárom, den 2. Mai 1998. Acta Archaeologica Brigetionensia Ser. I. Vol. 1. Budapest - Komárom 2000, 118-119.

BóNA, I.: A Brigetio canabaejában feltárt szoba mennyezetének rekonstrukciója - The reconstruction of the ceiling of the room discovered in the canabae of Brigetio. In: BorHy, L. (ed.): A római kori falfestészet Pannoniában. Nemzetközi konferencia a pannoniai falfestészet problémáiról. Komárom, 1998. május 2. - Die römische Wandmalerei in Pannonien. Internationale Fachkonferenz über Probleme der Wandmalerei in Pannonien. Komárom, den 2. Mai 1998. Acta Archaeologica Brigetionensia Ser. I. Vol. 1. Budapest - Komárom 2000, 120-123.

Borhy, L. (ed.): A római kori falfestészet Pannoniában. Nemzetközi konferencia a pannoniai falfestészet problémáiról. Komárom, 1998. május 2. - Die römische Wandmalerei in Pannonien. Internationale Fachkonferenz über Probleme der Wandmalerei in Pannonien. Komárom, den 2. Mai 1998. Acta Archaeologica Brigetionensia Ser. I. Vol. 1. Budapest - Komárom 2000.

Borhy, L.: Aeternae Quieti Perpetuae Securitati: Ein Sarkophagfund aus Brigetio. Zeitschrift für Papyrologie und Epigraphik 130 (2000) 253-256.

Borhy, L.: Römische Deckenmalerei aus Brigetio. In: Visy, Zs. (ed.): Von Augustus bis Attila. Leben am ungarischen Donaulimes. Schriften des Limesmuseum Aalen 53. Stuttgart 2000, 92-94.

BoRHy, L.: Bericht über die zwischen 1992-1996 in Brigetio (FO: Komárom/Szőny-Vásártér, Ungarn) freigelegten römischen Wandmalereien.In: BoRHy, L. (ed.): A római kori falfestészet Pannoniában. Nemzetközi konferencia a pannoniai falfestészet problémáiról. Komárom, 1998. május 2. Die römische Wandmalerei in Pannonien. Internationale Fachkonferenz über Probleme der Wandmalerei in Pannonien. Komárom, den 2. Mai 1998. Acta Archaeologica Brigetionensia Ser. I. Vol. 1. Budapest - Komárom 2000, 77-106.

Borhy, L. - Harsányi, E. - Kurovszky, Zs.: A Komárom/Szőny Vásártéren feltárt falfestménytöredékek 1994-1999. - Fragments of wall-paintings of a room excavated in Komárom/Szőny market place 1994-1999. In: PALÁGYi, S. (ed.): A kiemeléstől a bemutatásig - De la fouilles á la représentation - Von der Ausgrabung bis zur Präsentation. Nemzetközi kollokvium a római kori falfestményekröl - Colloque international pour la peinture murale de l'époque romaine - Internationales Kolloquium über römerzeitliche Wandgemälde. Veszprém 1999.05.17-18. Veszprém 1999 - 2000, 129-142. 
BoRHy, L.: Ausgewählte instrumenta inscripta Latina aus Brigetio (FO: Komárom/Szőny-Vásártér). In: NÉmeth, Gy. - Forisek, P. (eds.): Epigraphica I. Studies in Epigraphy. Hungarian Polis Studies 6. Debrecen 2000, 31-38.

Harsányi, E. - Kurovszky, Zs.: Beszámoló a Komárom/Szőny-Vásártéren feltárt mennyezetfestmény restaurálásáról - Bericht über das in Brigetio (FO.Komárom/Szőny-Vásártér) freigelegten Deckengemäldes. In: Borhy, L. (ed.): A római kori falfestészet Pannoniában. Nemzetközi konferencia a pannoniai falfestészet problémáiról. Komárom, 1998. május 2. - Die römische Wandmalerei in Pannonien. Internationale Fachkonferenz über Probleme der Wandmalerei in Pannonien. Komárom, den 2. Mai 1998. Acta Archaeologica Brigetionensia Ser. I. Vol. 1. Budapest - Komárom 2000, 107-116.

KRISTON, L.: A Szőnyben feltárt falképtöredékek röntgendiffrakciós vizsgálatának fontosabb eredményei. In: Borhy, L. (ed.): A római kori falfestészet Pannoniában. Nemzetközi konferencia a pannoniai falfestészet problémáiról. Komárom, 1998. május 2. - Die römische Wandmalerei in Pannonien. Internationale Fachkonferenz über Probleme der Wandmalerei in Pannonien. Komárom, den 2. Mai 1998. Acta Archaeologica Brigetionensia Ser. I. Vol. 1. Budapest - Komárom 2000, 116-117.

\section{9}

Bezeczky, T.: New amphora finds from Brigetio. Antaeus 24 (1999) 65-72, 600-601.

BoRHy, L.: Viharos leletmentés. Római kori szarkofágok a MOL Rt. Komáromi Finomítójában. Élet és Tudomány 54.6 (1999) 164-166.

Borhy, L. - SzÁmadó, E.: Brigetio kincsei. Kiállítási katalógus. Komárom 1999.

Borhy, L. - SzÁmadó, E.: Brigetio kincsei. Élet és Tudomány 54.6 (1999) 560-562.

Borhy, L. - SzÁmAdó, E.: A Komárom/Szőny-MOLAJ “A” út lelőhelyen feltárt római szarkofágok. In: Borhy, L. - SzÁmadó, E. (eds.): Brigetio kincsei. Kiállitásvezető. Komárom 1999, 3-16.

Borhy, L.: Az 1. sz. szarkofág felirata. In: Borhy, L. - SzÁmadó, E. (eds.): Brigetio kincsei. Kiállításvezetó. Komárom 1999, 17-18.

Borhy, L.: Támogatott leletmentés. Reader`s Digest Válogatás. 1999.6, 5.

Borhy, L. - SzÁmadó, E.: Instrumenta inscripta Latina aus Brigetio (FO: Komárom/Szőny-Vásártér). In: VAdAy, A. (ed.): Pannonia and Beyond. Studies in Honour of László Barkóczi. Antaeus. Communicationes ex Instituto Archaeologico Academiae Scientiarum Hungaricae 24. Budapest 1999, 95-115, 619-629.

BoRHy, L.: 1998 - Traianus éve. A brigetiói freskók bemutatkozása Olaszországban. Ancona, 1998. október 19 - 1999. január 17. Komáromi Újság 1999. február 25., 3.

Borhy, L.: A Komárom/Szőny-Vásártéri ásatás gemmaleletei. A Debreceni Déri Múzeum Évkönyve 1997-1998 [1999], 209-218.

DÁLNOKI, O.: A brigetiói szarkofágok földmintáinak archaeobotanikai elemzése. In: BoRHy L. SzÁmADó E.: Brigetio kincsei. Kiállításvezető. Komárom 1999, 31-34.

ÉRY, K.: A csontvázleletek embertani vizsgálata. In: BorHy, L. - SzÁmadó, E. (eds.): Brigetio kincsei. Kiállításvezető. Komárom 1999, 24-28.

FÉNyEs, G.: “Gagát”-karkötő a 3. sz. szarkofágból. In: BorHy, L. - SzÁmadó, E. (eds.): Brigetio kincsei. Kiállításvezető. Komárom 1999, 19-20. 
JÁRó, M.: A 2. sz. szarkofágban talált fémfonal-töredékek természettudományos vizsgálata. In: Borhy, L. - SzÁmadó, E. (eds.): Brigetio kincsei. Kiállításvezető. Komárom 1999, 29-30.

Miкцósıтy Szőke, M.: A 2. sz. szarkofágban talált gyöngyök. In: BoRHy, L. - SzÁmAdó, E. (eds.): Brigetio kincsei. Kiállitásvezetó. Komárom 1999, 20-24.

SzÁMADÓ, E.: A Komárom-Szőny Vásártéren 1992 és 1998 között folytatott ásatások eredményei. Atelier 2.1 (1999) 35-36.

SzÁmADÓ, E.: Római kori falfestmények a komáromi Klapka György Múzeum állandó kiállításán. Atelier 2.1 (1999) 37.

\section{8}

BoRHy, L.: Római kori falfestmények Brigetióból. Élet és Tudomány 53.29 (1998) 899-902.

BoRHy, L.: Római falfreskók Szőnyből, a római kori Brigetióból. In: Alapítvány a Magyar Felsőoktatásért és Kutatásért - Magyary Zoltán Posztdoktori ösztöndíjasok II. találkozója. Szeged, 1998. november 5-6. Szeged 1998, 3-7.

BoRHy, L.: Beszámoló a szőnyi Vásártéren és a Molaj területén 1998-ban végzett régészeti feltárások eredményeiről (I. rész). Komáromi Újság 1998. november 26., 3.

BorHy, L.: Leletmentés a Molaj területén: szarkofágok ép üvegedényekkel és aranyékszerekkel. Komáromi Újság 1998. december 17., 3.

BoRHy, L. - SzÁmadó, E.: Római kori falfreskók Komárom/Szőny-Vásártér lelőhelyről, az ókori Brigetioból. 1998. évi naptár, Komárom Város Önkormányzatának reprezentativ kiadványa. Komárom 1998.

BöDőcs, A.: A Komárom/Szőny-Vásártér lelőhelyen 1992-1996 között folytatott ásatások eredményeinek tértinformatikai kiértékelése. Unpublished MA-thesis. Budapest 1998.

FÉNYEs, G.: Mécsesek a Komárom/Szőny-Vásártéri ásatásokról. Ókortudományi Értesitő 2 (1998) 23-26.

FÉNYes, G.: A brigetiói municipium házi kerámiája a Komárom/Szőny-Vásártéri ásatásokról 1992-1996 (asztali kerámia és világítóeszközök).Unpublished MA-thesis. Budapest, 1998.

Miкцósity SzőKe, M.: A brigetiói municipium házi kerámiája a Komárom/Szőny-Vásártéri ásatásokról 1992-1996 (fözö- és tárolóedények). Unpublished MA-thesis. Budapest 1998.

\section{7}

BorHy, L.: Glasgemme mit antoninischem Frauenportrait aus Brigetio (Komárom/Szőny, Ungarn). Archäologischer Anzeiger 1997, 98-101.

BoRHy, L.: Wandmalereien aus Brigetio (Komárom/Szőny - Vásártér) und der Grabhügel 2 von Inota. - A Komárom/Szőny-Vásártér lelőhelyen talált római kori falfestmények és kapcsolatuk az inotai 2. számú halomsírhoz. Akten der 4. Internationalen Tagung über römerzeitliche Hügelgräber, Veszprém 10-15. September 1996. Balácai Közlemények 5 (1997) 161-169.

Borhy, L.: Pitture parietali romane da Brigetio in Pannonia: modelli classici e paralleli provinciali. In: Scagliarini, D. (ed.): VI Convegno Internazionale sulla Pittura Parietale Antica: I temi figurativi nella pittura parietale antica (IV sec. a.C. - IV sec. d.C.). Bologna 1997, 26-27.

Borhy, L. - SzÁmadó, E.: Az 1994. év régészeti kutatásai. Komárom (Szőny) - Vásártér. Régészeti Füzetek 48 (1997) 41-42.

Borhy, L. - SzÁmadó, E.: Az 1995. év régészeti kutatásai. Komárom (Szőny) - Vásártér. Régészeti Füzetek 49 (1997) 48-49. 
MikLósıty SzőkE, M.: Római kori üveggyöngyök Brigetióból. Archaeologiai Értesítő 123-124 (19961997) 169-177.

SzÁmadó, E.: Brigetio kutatástörténete. Komárom-Esztergom Megyei Múzeumok Közleményei 5 (1997) $149-174$

\section{6}

BAlogh, E.: Ónix gemma Mars ábrázolással In: Borhy, L. - SzÁmadó, E.: Válogatás a Szőny-Vásártéri ásatás leleteiből (1992-1995). Kiállítási katalógus. Komárom 1996, 11-12.

Beck, T.: A római kori luxuskerámia: a terra sigillata. In: Borhy, L. - SzÁmadó, E.: Válogatás a Szőny-Vásártéri ásatás leleteiből (1992-1995). Kiállitási katalógus. Komárom 1996, 19-23.

BECK, T.: Brigetiói terra sigillaták (1992-1993). Unpublished MA-thesis. Budapest 1996.

Borhy, L.: Zur Tätigkeit einer fabrica falsaria in Brigetio (Komárom/Szőny, Ungarn). Archäologisches Korrespondenzblatt 26.3 (1996) 311-321.

BoRHy, L.: Római kori falfreskók Brigetióból (Előzetes beszámoló a Szőny - Vásártér lelőhelyen 1994ben talált falfestményekről). Antik Tanulmányok 45.1-2 (1996) 199-210.

BoRHy, L.: Római kori freskóleletek a szőnyi Vásártérről és építészeti összefüggéseik (1994-1995). In: Borhy, L. - SzÁmadó, E.: Válogatás a Szőny-Vásártéri ásatás leleteiből (1992-1995). Kiállítási katalógus. Komárom 1996, 3-10.

Borhy, L.: Női portréval díszített üveggemma. In: BorHy, L. - SzÁmadó, E.: Válogatás a Szőny-Vásártéri ásatás leleteiből (1992-1995). Kiállitási katalógus. Komárom 1996, 12-14.

Borhy, L. - SzÁmadó, E.: Válogatás a Szőny-Vásártéri ásatás leleteiből (1992-1995). Kiállitási katalógus. Komárom 1996,

Borhy, L. - SzÁmadó, E.: Az 1993. év régészeti kutatásai. Komárom (Szőny) - Vásártér. Régészeti Füzetek 47 (1996) 38-39.

FÉNyes, G.: Római kori mécsesek a Vásártérről. In: BorHy, L. - SzÁmadó, E.: Válogatás a SzőnyVásártéri ásatás leleteiből (1992-1995). Kiállitási katalógus. Komárom 1996, 23-26.

MikLósity SzőKE, M.: Üveggyöngyökből és korallszemekből álló nyakék Brigetióból. In: BoRHy, L. SzÁmadó, E.: Válogatás a Szőny-Vásártéri ásatás leleteiből (1992-1995). Kiállitási katalógus. Komárom 1996, 14-19.

\section{5}

Borhy, L. - SzÁmadó, E.: A Szőny-Vásártéri freskólelet. Kiállításvezető. Komárom 1995.

\section{4}

Borhy, L.: Romani e Pannoni. Aspetti dell'acculturazione in una provincia di frontiera. In: HAjNóczy, G. (ed.): Atti del convegno „La Pannonia e l'Impero Romano. Identitá e divergenze” (Roma, 13/16 Gennaio 1994). Annuario dell'Accademia d'Ungheria a Roma. Roma 1994, 71-82.

Borhy, L. - SzÁmadó, E.: Az 1992. év régészeti kutatásai. Komárom (Szőny) - Vásártér. Régészeti Füzetek 46 (1994) 41-42. 